\title{
Disseminated coccidioidomycosis masquerading as recurrent lymphoma
}

\author{
Marie A Manning, ${ }^{1}$ Phillip H Kuo, ${ }^{2}$ Andrew M Yeager ${ }^{1}$
}

${ }^{1}$ Medicine and Cancer Center, University of Arizona College of Medicine, Tucson, Arizona, USA ${ }^{2}$ Medical Imaging, University of Arizona College of Medicine, Tucson, Arizona, USA

\section{Correspondence to} Professor Andrew M Yeager, ayeager@email.arizona.edu

Accepted 10 May 2018

\section{DESCRIPTION}

Infection with Coccidioides immitis, a soil-dwelling fungus endemic to the American Southwest, may have protean manifestations in immunocompromised patients who reside in ${ }^{12}$ or who have travelled to ${ }^{3}$ that region. We report a patient whose abnormal PET/CT scan raised concern for recurrent lymphoma but instead was due to disseminated coccidioidomycosis.

A 62-year-old woman was diagnosed with ileocaecal marginal zone lymphoma (MZL) after presenting with iron-deficiency anaemia and faecal occult blood. Ten years earlier, she underwent allogeneic haematopoietic cell transplantation for acute myeloid leukaemia (AML). She had recurrent cutaneous chronic graft-versus-host-disease (CGVHD); 50 months before the diagnosis of MZL, she completed a 9-month course of prednisone $(50 \mathrm{mg}$ every other day) and did not receive any further corticosteroid therapy. At the time of diagnosis of MZL, the patient was receiving twice-monthly extracorporeal photopheresis (ECP), which had been initiated 1 year earlier for the most recent flare of cutaneous CGVHD.

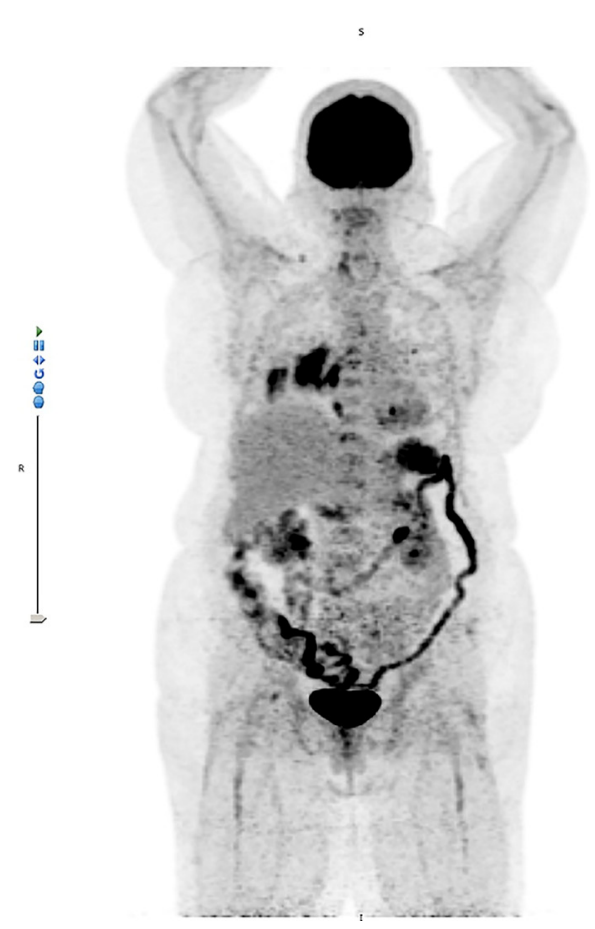

Figure 1 PET/CT scan 29 months after local radiotherapy for marginal zone lymphoma, showing new fluorodeoxyglucose-avid intrathoracic and extrathoracic adenopathy, left upper and right lower lobe masses, multiple vertebral body lesions and splenomegaly.

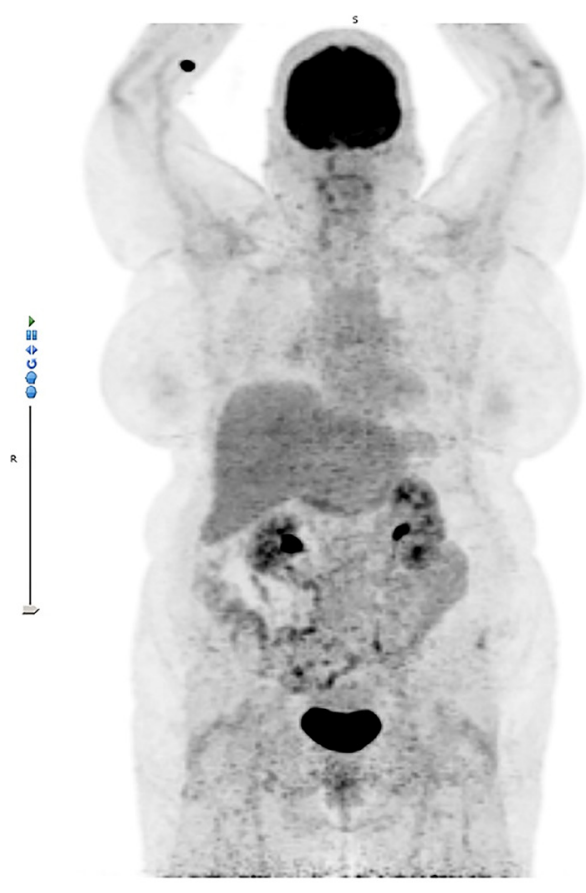

Figure 2 PET/CT scan after 8 months of treatment with fluconazole, showing complete resolution of fluorodeoxyglucose-avid lesions.

She received regional 3D conformal radiotherapy, with a total dose of 24 Gy delivered over 12 daily fractions of 2 Gy. For 1 year after treatment of MZL, she also continued on ECP for CGVHD. PET/CT scans at 3, 6, 12 and 18 months post-radiotherapy were negative. However, a PET/CT scan 29 months post-treatment showed multiple fluorodeoxyglucose (FDG)-avid areas in the left upper and right lower lobes (standardised uptake value (SUV) 4.7 and 9.4, respectively), right infrahilar region (SUV 17.3), hilar (SUV 12.0), retrocrural (SUV 7.9) and para-aortic (SUV 8.9) nodes, and several vertebral bodies (SUVs 6.3 to 6.9) (figure 1).

Because these findings were suspicious for recurrent lymphoma, the patient underwent a CT-guided biopsy of the right lung mass, which showed haemorrhagic tissue and acute and chronic inflammation but no granulomata, organisms or malignancy. On additional questioning, the patient recalled a remote history of possible coccidioidomycosis; she had lived in Arizona, USA, for more than 30 years. Serological studies for Coccidioides showed positive $\mathrm{IgG}$ and indeterminate IgM by enzyme immunoassay; further quantitation with complement-fixation titres was not performed. 


\section{Learning points}

- Disseminated coccidioidomycosis is a protean disease that can be confused with fluorodeoxyglucose-avid malignancy.

- When evaluating either immunocompromised or immunocompetent patients with medical imaging studies that suggest pulmonary and/or skeletal manifestations of a disseminated or focal neoplastic process, one should obtain a thorough history of residency in or travel to regions where Coccidioides is endemic.

The patient began treatment with oral fluconazole $(400 \mathrm{mg}$ daily) for disseminated coccidioidomycosis. Eight months later, a PET/CT scan showed resolution of FDG-avid areas (figure 2). The patient completed a 12-month course of fluconazole and has had no recurrences of coccidioidomycosis, lymphoma, AML or CGVHD.
Contributors MAM and AMY conceived and planned this report. PHK assisted with acquisition and interpretation of images. All authors contributed to the writing and editing of this report.

Funding The authors have not declared a specific grant for this research from any funding agency in the public, commercial or not-for-profit sectors.

Competing interests None declared.

Patient consent Obtained.

Provenance and peer review Not commissioned; externally peer reviewed.

(c) BMJ Publishing Group Ltd (unless otherwise stated in the text of the article) 2018. All rights reserved. No commercial use is permitted unless otherwise expressly granted.

\section{REFERENCES}

1 Blair JE, Smilack JD, Caples SM. Coccidioidomycosis in patients with hematologic malignancies. Arch Intern Med 2005;165:113-7.

2 Singh VR, Smith DK, Lawerence J, et al. Coccidioidomycosis in patients infected with human immunodeficiency virus: review of 91 cases at a single institution. Clin Infect Dis 1996;23:563-8.

3 Hombach M, Stulz P, Arnold W, et al. Pulmonary Coccidioides nodule in a Swiss patient with chronic lymphatic leukaemia. J Med Microbiol 2008;57:1427-30.

Copyright 2018 BMJ Publishing Group. All rights reserved. For permission to reuse any of this content visit

http://group.bmj.com/group/rights-licensing/permissions.

BMJ Case Report Fellows may re-use this article for personal use and teaching without any further permission.

Become a Fellow of BMJ Case Reports today and you can:

- Submit as many cases as you like

- Enjoy fast sympathetic peer review and rapid publication of accepted articles

- Access all the published articles

Re-use any of the published material for personal use and teaching without further permission

For information on Institutional Fellowships contact consortiasales@bmjgroup.com

Visit casereports.bmj.com for more articles like this and to become a Fellow 